\title{
Flight on the Jacobean stage
}

\section{Shokhan Rasool Ahmed}

English Department, University of Sulaimani, Sulaimani/Kurdistan, Iraq

\section{Email address:}

shokhan_rasul@yahoo.com

\section{To cite this article:}

Shokhan Rasool Ahmed. Flight on the Jacobean Stage. International Journal of Literature and Arts. Vol. 2, No. 5, 2014 , pp. $192-210$. doi: 10.11648/j.ijla.20140205.17

\begin{abstract}
This study is concerned with the historical and theatrical aspects of Middleton's The Witch. Among the questions it will address are which sources Middleton drew on for this play, and to what extent his witches differ from those in Shakespeare's Macbeth. This chapter (paper) also considers the question of whether the treatment of witchcraft in Middleton's The Witch belongs to the English or the Continental tradition. While the historical circumstances of witchcraft ideas are important for an understanding of this play, this paper will demonstrate that questions of genre and visual spectacle are equally important; especially it will argue that the play's comedy and its visual aspects are mutually dependent. In raising the issue of why the play is categorized as tragicomedy, I examine how comedy and technology come together in this play. Finally, this study explores how the play would have worked on stage, and especially how the witchcraft scenes would have been staged to create a theatrical spectacle: what props, or other staging devices were needed, and how these were adapted during the Renaissance period. The question is also raised here as to when the machinery for staging flying witches came into existence, and whether the stage directions of the supernatural scenes in The Witch and some of Shakespeare's later plays, Cymbeline and The Tempest, were originally written by the actual authors or scrivener. This paper also examines differences in stage directions for supernatural characters between early modern and contemporary editions of the above plays.
\end{abstract}

Keywords: Stage Directions in Thomas Middleton's The Witch, Hecate and her Flight at the Blackfriars, Shakespeare's Cymbeline and The Tempest

\section{Introduction}

Middleton as a playwright wrote several plays and worked with different companies. During Middleton's lifetime several pieces of his work were publicly burned and condemned at Paul's Cross, and banned by the Privy Council. ${ }^{1}$ Middleton started writing plays as a freelance playwright: he was not tied to working for one company. He began to accompany the players of the Blackfriars during the War of the Theatres. ${ }^{2}$ During his early work, Middleton wrote plays for the Admiral's Men at the Fortune in 1602-03 and then for Paul's boys between 16031607 , followed by one or perhaps two plays for the

\footnotetext{
${ }^{1}$ Gary Taylor, 'Thomas Middleton: Lives and Afterlives', in Thomas Middleton the Collected Works, ed. by Gary Taylor and John Lavagnino (Oxford: Clarendon Press, 2007), pp.25-58 (p. 25).

${ }^{2}$ Scott MacMillin, 'Middleton's Theatres', in Thomas Middleton: the Collected Works, ed. by Gary Taylor and John Lavagnino (Oxford: Clarendon Press, 2007), pp. $74-87$ (p. 38).
}

Children's company at the Blackfriars. ${ }^{3}$ He wrote both tragedy and comedy for these companies. Some of his comedies, which were contemporary satires, were performed by children's companies which specialised in these plays and were renowned for their splendid costumes. ${ }^{4}$ They also could 'act with a charm and a grace that often made them more attractive than their grown-up rivals'. ${ }^{5}$ However, because they performed Chapman's Conspiracy and Tragedy of Charles, Duke of Byron, an order was made forbidding them from putting on plays, and thus the King's Men took over the Blackfriars. ${ }^{6}$

After Middleton wrote plays for the Children's Company at Blackfriars, he moved on to the Lady Elizabeth Company and later the Kings Men. However, some of his

\footnotetext{
${ }^{3}$ Ibid., pp. 76-7.

${ }^{4}$ Ibid., p. 77.

${ }^{5}$ Joseph Quincy Adams, Shakespearean Playhouses: A History of English Theatres from the Beginning to the Restoration (Gloucester: Peter Smith, 1960), p. 207.

Ibid., pp. 220-22
} 
plays were still staged by the Admiral's Men at the Globe. The King's Men moved from the Globe to Blackfriars, using Blackfriars as a 'winter house' and the Globe as a 'summer house'. The King's Men performed The Witch at Blackfriars alongside Shakespeare's late plays such as The Tempest (1610-11) and Cymbeline (1611). Taken together, these plays suggest that the King's Men Company had an interest in staging plays with scenes of supernatural spectacle in them during the second decade of the seventeenth century, it is likely that Middleton wrote The Witch, a play dealing with the supernatural power of witches, in order to better suit the speciality of the King's Men and the technology of the private theatre of Blackfriars and in doing so to further his career.

Although not all of Middleton's plays were published during his lifetime, six of them were The Roaring Girl (printed in 1611), Masque of Heroes (1619), The World Tossed at Tennis (1620), Measure for Measure (1623), Timon of Athens (1623), and The Witch (transcribed in 1625?). ${ }^{8}$ The latter was transcribed by Ralphe Crane into a small quarto-seized manuscript. ${ }^{9}$ Crane named "Tho. Middleton" in his scribal transcript The Witch, Malone MS 12 , on the title page and below Middleton's dedicatory epistle but we are not sure whether Middleton ever saw this manuscript, or inserted its table. Bullen thought that the manuscript of The Witch was recovered from the King's Men Company at the Blackfriars, through the dedicatory epistle of Malone MS 12 that he wrote to Thomas Holmes. ${ }^{10}$ Thomas Holmes worked with the King's Men at the Blackfriars and was a close friend to Thomas Middleton.

\section{Flight on the Jacobean Stage}

\subsection{The Witch: An Introduction to the Play}

Through the dedicatory epistle - 'Witches are (ipso-facto) by $\mathrm{y}^{\mathrm{e}}$ Law condemn'd, \& y ${ }^{\mathrm{t}}$ onely (I thinck) hath made her lie so-long, in an imprisond-Obscuritie,11 - Middleton's The Witch seems to have been composed, if not performed, at an earlier period, and the play was written before the dedication. However, the play was probably suppressed for legal or censorship reasons. Samuel Johnson and George Steevens argue that the dedication was added to the play

\footnotetext{
${ }^{7}$ Ibid., p. 225.

${ }^{8}$ Gary Taylor, 'The Order of Persons', in A Companion to the Collected Works: Thomas Middleton and Early Modern Textual Culture, ed. by Gary Taylor and John Lavagnino (Oxford: Oxford University Press, 2007), pp. 31-79 (p. 52). Some works have only recently been assigned to Middleton as possible collaborations, and Shakespeare is the named author (Measure for Measure, and Timon of Athens)

${ }^{9}$ John Jowett, 'From Many of Your Companies: Middleton's Early Reader', in A Companion to the Collected Works: Thomas Middleton and Early Modern Textual Culture, ed. by Gary Taylor and John Lavagnino (Oxford: Clarendon Press, 2007), pp. 286-327 (p. 295).

${ }^{10}$ Thomas Middleton, The Works of Thomas Middleton, ed. by A. H. Bullen, 8 vols (New York: AMS press INC, 1964), V, p. 355.

11 Thomas Middleton, The Witch: A Tragi-coomodi, Called the Witch (Louvain: Librairie: Ch. Uystpruyst, 1945), p. 3.
}

soon after 1603 when the act of King James against witches [was] passed into a law. ${ }^{12}$ The play was acted by his Majesty's servants who had been before in the service of the Queen, but Middleton dedicated The Witch in the time of King James. This suggests the play was written earlier than 1616 as some critics relate the date of this play to the contemporary scandal of Lady Howard and the Somerset family (1613) and the Overbury poisoning trial in $1616^{13}$

The play consists of three basic plots: the first concerns the relationship between a husband and wife, Antonio and Isabella, and Sebastian (previously contracted to Isabella). Having been falsely informed that Sebastian has been killed in the wars of Italy, Isabella has married Antonio, yet Sebastian reappears and persists in his attempt to win his fiancée back. This plot seems to be a response to the real divorce of Lady Frances Howard in 1613 and the Overbury poisoning trial in May 1616. Lady Frances Howard married Robert Devereux, the Earl of Essex, in early 1606 and then, after the annulment of the marriage, was married to Robert Carr, Earl of Somerset, at the end of $1613 .{ }^{14}$ The relationships of Carr, Howard and Devereux are similar to those between the characters Sebastian, Isabella and Antonio in The Witch. Middleton recasts the characters in the mould of the contemporary scandal in the first plot of The Witch. However, the character of Francisca (Antonio's sister, who loves Aberzanes and is secretly pregnant) resembles Frances Howard and dominates the second plot. One can find name resemblance between Frances and Francisca. She is the same age (sixteen) as the countess, when the Earl of Essex returned from France and tried to consummate their marriage. The popular image of Howard is linked to Francisca in terms of sexual morals. Francisca is pregnant like Frances Howard: the Overbury murder trial was delayed because of her pregnancy and her daughter, Anne, was born in December 1615. The third plot is dominated by the Duchess, who seeks revenge upon the Duke, and is followed by her plot to dispose of her agent, Almachildies. The Duchess consults Hecate for poison to kill the Duke first (since he humiliates her by drinking a toast with a cup which was made from her own father's skull) and then Almachildies (the Duchess plots with him to kill the Duke but the plan is not successful). However, the audience discovers that neither the Duke nor Almachildies dies. This plot is taken from the Italian Florentine History of Niccolo Machiavelli. In this story, Rosamund, the daughter of the King of Lipdes, Comundus,

\footnotetext{
${ }^{12}$ Samuel Johnson and George Steevens, William Shakespeare: in Twenty-One Volumes(London: 1813), ii, p. 343.

${ }^{13}$ For a discussion of the date of composition of the play, see Terence P. Logan \& Denzell S. Smith, The Popular School: A Survey and Bibliography of Recent Studies in English Renaissance Drama (Lincoln: University of Nebraska, 1975), p. 69. See also Stephan Orgel, 'A Critical Edition of Thomas Middleton's Your Five Gallants' (unpublished doctoral thesis, University of Michigan, 1961), p. 5.

${ }^{14}$ Marion O'Connor, 'The Witch', in Thomas Middleton: The Collected Works, ed. by Taylor and Lavagnino (Oxford: Oxford University Press, 2007), pp. 1124-64 (p. 1124).
} 
attempted revenge upon her husband, Alboinus. This was because Alboinus insisted that she drank toasts from a cup which was made of Comundus's skull, and out of it used to carouse in memory of that victory. Rosamund consulted with Almachildies, a noble Lombard, to kill Alboinus in return for admitting him by night to her chamber. Almachildies agreed to murder Alboinus but the plan was not successful and finally he fled to Longinus at Ravenna. ${ }^{15}$

Diane Purkiss argues that the story of Frances Howard can be found in The Witch in the scene with the cunning woman, Anne Turner, the woman whom Howard allegedly consulted with about keeping her husband impotent, in relation to Middleton's Hecate. Sir Thomas Overbury was a very close associate and advisor to Robert Carr, however Carr quarrelled with him, believing him to have had an illicit relationship with his wife Lady Frances. Overbury died on 14 September 1613, four months after being arrested and imprisoned in the Tower at the request of Lady Frances' family and James I. Initially his death was considered natural but it was later thought to be an act of poisoning. Rumours of the poisoning and murder of Overbury by Carr and his countess spread among the public. Lady Frances Howard was accused of consulting with cunning women and men to cause her husband's impotence and obtaining the poison used to murder Overbury. In the Essex divorce case, there was another cunning woman named Mary Woods, who cozened Frances Howard by taking a jewel in exchange for poison. A witness named Isabel Peel was also involved in the case and gave evidence that Mary Woods deceived a number of women into believing that she was able to cause their husbands' impotence. Thus, they were accused of these alleged crimes and condemned to death. However, they both received royal pardons.

It has also been suggested that The Witch was inspired by the success of the entertainment in Jonson's The Masque of Queens $(1609)^{16}$, which was performed for the first time in Whitehall Palace. Indeed, some critics argue that the witches' dances in both Macbeth and The Witch were inspired by the witches' dance in The Masque of Queens. ${ }^{17}$ The three writers all utilised a cauldron scene in which witches dance and sing around a cauldron during their magical rites. The cauldron scene in the three plays also serves the purpose of presenting the portrayal of witchcraft rituals to the audience. There is still doubt over whether Middleton was primarily inspired by Macbeth (1606) or The Masque of Queens (1609). It is possible to say that Middleton drew most directly on Jonson, but that during the time Middleton wrote The Witch the King's Men

\footnotetext{
${ }^{15}$ The Works of Middleton, ed. by Bullen, pp. 353-4.

${ }^{16}$ F. P. Wilson, The Witch (Britain: The Malone Society Prints, 1948 (1950)), p. vi.

${ }^{17}$ See Peter Corbin and Douglas Sedge, Three Jacobean Witchcraft Plays: The Tragedy Sophonisba, The Witch, The Witch of Edmonton (Manchester and New York: Manchester University Press, 1986), p. 17, Anthony Harris, Night's Black Agents: Witchcraft and Magic in Seventeenth-century English Drama (Manchester: Manchester University Press, 1980), pp. 83-6.
}

were able to perform Hecate scenes (flying witches) at Blackfriars in the later years of 1609 , as part of a revived version of Macbeth at the playhouse.

Middleton's witches adhere to Simpson's definition of a witch as being a, 'member of a secret sect of Satanworshippers who meet regularly and practise ritual murder, cannibalism and sexual orgies.' 18 Moreover, characteristically such a witch can fly by night and ride on strange animals. Hecate in Middleton's The Witch works through the aid of the devil, has several sexual orgies and flies in the night (Act 1, scene 2). Middleton's Hecate is thus recognisably a witch of the traditional type. She is female, poor and old, as she succinctly reveals in her words foretelling her death to her son Firestone:

\section{Thou shalt have all when I die; and that wilbe}

Ev'n just at twelue a Clock at night, come three yeare (I.ii. 256-257) ${ }^{19}$

Middleton's witches are not scary and do not have a serious effect on the family affairs of those outside their own circle. They aim to satisfy their own lusts by sleeping with visitors, succubi and their own offspring. In The Witch, as well as in Macbeth, the witches do not involve themselves with the other characters as a result of their own plot, but they work according to the request of the characters who visit them.

In Act 1, scene 2, the witches introduce themselves to the audience through their speech. Hecate has conversations with her minion Stadlin, Sebastian, her son Firestone and with Almachildies. Hecate's familiar spirits enter the stage; Malkin, a spirit like a Cat, and the others carrying meat with a list of magical ingredients. After their conversations, the scene continues with the presence of the witches' cauldron and then their festivities:

\section{Appear to our sight then ev'n leeke}

A russet-Moale, vpon some Ladies cheeke.

When hundred Leagues in Air, we feast, and sing,

Daunce, kisse, and coll, vse everything (I.ii.210-213)

These types of activities, such as feasting, singing, dancing, kissing and embracing also characterise Ben Jonson's hags, and their adventures are similarly described in festive terms. Middleton directly reuses the same vocabulary used earlier by Reginald Scot: 'They seeme to be carried in the aire, to feasting, singing, dansing, kissing, culling, and other acts of venerie, with such youthes as they love and desire most. ${ }^{20}$ By describing these activities, Middleton presents to the audience a comic portrayal of the supernatural, especially when the witches confront the audience with unexpected revelations and reversals of fortune. Middleton borrows several further items of

\footnotetext{
18 Jacqueline Simpson, 'Witches and Witchbusters', Folklore, 107 (1996), 518 (p. 12).

${ }^{19}$ Wilson, The Witch, p.11.

${ }^{20}$ Reginald Scot, The Discovery of Witchcraft (New York: Dover publications, 1972), p. 105.
} 
vocabulary from Scot concerning the witches' activities and the ingredients they use with some devilish names. Having used Scot's The Discovery of Witchcraft as a source for his play implies scepticism on Middleton's part about the truth of witchcraft (King James ordered every copy of Scot's book to be destroyed as he disagreed with its sceptical viewpoint). ${ }^{21}$ However, clearly Scot's text remained influential: Middleton, Shakespeare and Jonson all drew on it for the depiction of their witches and witch scenes in their plays.

\subsection{Witches in the Witch and Macbeth}

Both Macbeth and The Witch reflect a period in time when belief in witchcraft and the practice of witch-hunting were very strong. ${ }^{22}$ They were both written in the same reign but have subtle and telling differences in their approaches to witchcraft. The witches of Middleton are only seen at night, as we have seen, the witches of Macbeth often appear in the context of thunder and lighting. In another scene after Macbeth has been made king and Lady Macbeth queen, the three witches meet Hecate, and Hecate tells the spirits to

\section{Get you gone, \\ And at the pit of Acheron \\ Meet me i'th' morning. Thither he \\ Will come to know his destiny. (III.v.14-17) ${ }^{23}$}

However, in the same quotation Hecate is going to spend the night 'unto a dismal and a fatal end' (III.v.20-21). Then she orders the other witches that the great business should be done before noon:

Great business must be wrought ere noon.

Upon the corner of the moon

There hangs a vap'rous drop profound. (III.v.21-23)

Like Middleton's Hecate and witches, Macbeth's Hecate and witches also go riding at night:

\section{[Spirits and Hecate] \\ $O$ what a dainty pleasure 'tis \\ To ride in the air \\ When the moon shines fair, \\ And sing, and dance, and toy, and kiss. (III.v.58-61)}

The witches mentioned in both plays complete their activities and make their charms in the moonlight. Night time is the traditionally appropriate setting for these evil characters, as night time or darkness both hides and complements the evil nature of the witches. As Briggs observes, 'black witchcraft is the magic of sterility; the moon's waxing time has always been counted the time of

\footnotetext{
${ }^{21}$ Frank Robert Donovan, Never on a Broomstick (Harrisburg, PA: Stackpole Books, 1971), p. 169.

${ }^{22}$ Albert H. Tolman, 'Notes on Macbeth', PMLA, 11 (1896), 200-219 (p.208).

${ }^{23}$ William Shakespeare, Macbeth, ed. by A. R. Braunmuller (Cambridge: Cambridge University Press, 1997), p. 185.
}

growth, and the moon's eclipse therefore would be the time of complete negation.' ${ }^{24}$ Accordingly, Hecate and the Spirits in both plays are not entirely evil since they ride in the air and do the other activities when the moon is shining, but not when the sky is quite dark. However, they are still considered as creatures of darkness or night because they do not make their charms in daylight. What can be said here is that Hecate and her fellow witches do not appear entirely evil when compared with the Weird Sisters, and the Hecate materials added to the play operate as an entertaining interlude within the play.

The similar times of day when the witches appear in both plays is clear, but there remain several other differences between the portrayal of the witches in the two plays. For instance, Middleton's The Witch is set in 'Jacobean' Italy, mirroring an element of satire about witch belief and practice both in Jacobean England and in the Roman Catholic societies of Middleton's period; the witch scenes are concerned with the way the witches use their charms and achieve transvection (flying for some thousands of miles in the air at midnight by using a kind of ointment). In Macbeth, the witches are prophetic, making prophecies about the characters of Macbeth and Banquo. Moreover, their predictions come true by the end of the play: their prophecies lead to Macbeth's murder of Duncan, as well as the deaths of Banquo and his son. By contrast, the spells of the witches in The Witch do not always work.

Approaches to gender also differentiate the two plays. The gender of the witches in Macbeth is ambiguous. At the beginning of the play, Banquo is confused by the three sisters having beards and is unable to decide whether they are earthly or supernatural creatures and whether they are women or men:

What are these,

So withered, and so, wild in their attire,

That look not like th' in habitants $o^{\prime}$ th' earth

And yet are on 't? Or are you aught

That man may question? You seem to understand

By each at once her choppy finger laying

Upon her skinny lips. You should be women,

And yet your beards forbid me to interpret

That you are so. (I.iii.37-45)

Here, the physical ambiguity of the witches evokes a shift from order to disorder and confusion. Their physical appearances indicate masculine players rather than feminine, which reminds us that the roles of the witches were played by males (boys) at that period. However, the gender identity of the witches in The Witch is obvious; they consist of women and one man, Firestone. Whereas, Macbeth's Hecate does not have a child, Middleton's Hecate has a son that assists her in making spells. This shows that Middleton's witches are recognizably female

\footnotetext{
${ }^{24}$ K. M. Briggs, Pale Hecate's Team: an Examination of the Beliefs on Witchcraft and Magic among Shakespeare's Contemporaries and His Immediate Successors (London: Routledge and Kegan Paul, 1962), p. 80.
} 
and have a feminine appearance.

Furthermore, Macbeth's witches' physical appearance is described as being threatening and uncanny. They are not sexual, and are part of the tragic scenes, influencing the actions of the play to some extent. Middleton's witches also appear to be scary and horrific when Sebastian remarks of the appearance of Hecate: 'my horrors are so strong and great already/ That thou seem'st nothing. Up and laz not! (I.ii. 119-120). Despite their horrific appearance, though, they operate in the play for entertainment and comedic effect. In other words, they are objects of humour rather than horror, and unlike Macbeth, are also always sexually driven. The witches are part of the comic scenes and they do not try to influence the actions of other characters: they do not appear to others unexpectedly, but instead occupy a passive role, allowing people to come to them.

\subsection{Hecate in Both Macbeth and The Witch}

In The Witch, Hecate's activities include flying, conducting the witches' covens, cooking dead infants, as well as a number of other things that witches were believed to do, such as casting spells, melting wax images and dancing around the cauldron. Elizabeth Schafer rightly notes that the witch scenes are entertaining, "visually impressive, and there is a powerful dramatic tension produced by the juxtaposition of the wild, fantastic and funny witch scenes with the moody, troubled and murderous court scenes'. ${ }^{25}$ The witch scenes provide a mocking commentary on the court scenes which evoke parallels with the affairs of the Somerset family. Hecate's appearance is fearful, although no information is provided about her costume when she enters with her fellow witches. Later, at the end of act three, as Hecate and her fellow witches prepare for flight, Hecate enters the stage to join her familiar spirit cat, Malkin, to go riding in the air. Audiences would have been impressed by the visual staging of Hecate and Malkin flying in the air. This visual witch scene ridicules all such beliefs that witches had power over the natural order in early modern England. The witch scenes also condemn the corrupt society of early modern England as a whole instead of focusing on specific individuals.

In order to understand how Middleton treats questions of supernatural power and agency and depicts his witch characters, it is helpful first to consider how Hecate operates in Shakespeare's play. One of the supernatural powers used in Macbeth is the witches' ability to summon the mighty goddess of destiny: Hecate. In Act Three Scene Five, she is seen as the leader of the Weird Sisters and complains that the three sisters have excluded her from their meeting with Macbeth:

FIRST WITCH: Why how now, Hecate, you look angerly?

\footnotetext{
${ }^{25}$ Elizabeth Schafer, The Witch: Thomas Middleton (London and New York: A and c Black, 1994), p. xxvi.
}

\section{HECATE: Have I not reason, beldams, as you are, Saucy and over-bold? How did you dare To trade and traffic with Macbeth In riddles and affairs of death? And I the mistress of your charms The close contriver of all harms, Was never called to bear my part (III.v.1-8)}

Hecate then continues that Macbeth will come to her and that she knows about his destiny through the charms and spells she makes. Macbeth will also see apparitions through Hecate's charms:

\section{Meet me i'th'morning. Theither he \\ Will come to know his destiny \\ Your vessles and your spells provide,}

\section{Your charms and everything beside. (15-18)}

In the end of this scene, Hecate also reveals an important aspect about Macbeth's destiny, namely that he believes that he is untouchable, a conviction which ultimately leads to his downfall:

\section{And, you all know, security \\ Is mortals' chiefest enemy. (32-33)}

One can say that Hecate has a major influence upon the other witches in the play and this is why she is the goddess of witchcraft. The addition of the Hecate scenes changes the nature of the witches' intervention. A. C. Bradley pointed out that the witches in Macbeth 'are not goddesses, or fates, or in any way whatsoever, supernatural beings. They are old women, poor and ragged, skinny and hideous, full of vulgar spite $(\ldots) .{ }^{, 26} \mathrm{He}$ then argues that Macbeth was tempted solely by himself since he speaks of their supernatural soliciting but they did not actually solicit this. They merely foreshadowed his future in announcing his three prophetic titles. However, one can see that in the contexts presented above, Hecate makes charms and spells in order to reveal Macbeth's destiny and tells him about his future downfall.

The other witches are named as "the Weird Sisters" who are 'creatures of an elder world', Tolman notes, and they cannot be questioned by Macbeth. ${ }^{27}$ Muir argues that the Weird Sisters are not in fact witches, but demons or devils in their human form: "whether one considers them as human witches in league with the power of darkness, or as actual demons in the form of witches, or as merely inanimate symbols, the power which they wield or represent or symbolizes is ultimately demonic. ${ }^{, 28}$ Although Muir takes Macbeth's witches as actual demons, but they do not have a pact with the devil or their familiars. In other words, no demonic pact is seen in Macbeth and they are

\footnotetext{
${ }^{26}$ A.C. Bradley, Shakespearean Tragedy (New York: Palgrave, 1992), pp. 289299.

27 Tolman, 'Notes on Macbeth', p. 211.

28 See Curry cited in Kenneth Muir, The Arden Shakespeare: Macbeth (London: Methuen, 1951), p. iiv.
} 
classed as English village witches; they are not demons and devils, but witches. In contrast to Muir, Purkiss argues that the witches in Macbeth are in fact witches, rather than simply uncanny old women. The language of their speech 'is marked off from that of the other characters in a manner which insists on their iconic status and also on their difference from the human. ${ }^{, 29}$ Purkiss's concentration is on the type of language that the witches use, rather than their activities. The language of the witches is different from the language typically used by the other characters of the play, and they also speak differently when speaking among themselves from the way they speak to Macbeth.

In Macbeth the witches are hag-like, since Banquo describes them as 'withered' and 'wild' in their attire (I.iii. 40). In The Witch, Sebastian refers to Hecate as a hag: 'That I may never need this hag again' (I.ii.179). In another scene, Firestone refers to Hecate thus: 'I am sure they'll be a company of foul sluts there tonight' (III.iii.16). Firestone uses the word 'slut' to address the witches, which means a slovenly or lewd woman in the early modern context. ${ }^{30}$ The word 'hag' and 'beldame' can be found in almost all the witch plays. The characteristics of Hecate are borrowed from witchcraft treatises, namely that she is old, lewd, dependent, and has fellow witches. Both Hecate in Macbeth and The Witch appear to commit crimes and their crimes take place during their magical rites and Sabbath. However, they still form the comic part of the play.

\subsection{The Witches'Sabbath}

This topic is important for my discussion of the plays because one can learn about the crimes and infanticide the witches commit, and the pact they make with the devil during their Sabbath journey. Witch-Sabbath occurs in The Witch, Macbeth, The Late Lancashire Witches and Sophonisba. However, it is not practised BY [by] the witches of other plays, such as The Witch of Edmonton, Mother Bombie and The Wise Woman of Hogsdon. The time that witches traditionally were thought to hold their meetings to worship the devil was called the Sabbath. During this ceremony they made pacts and partook in sexual orgies with the devil and others such as succubi and incubi. Briggs quotes the critical view of the French judge Pierre de Lancre on the purpose of the witches attending the Sabbath, which was to:

Dance indecently, to banquet filthily, to couple diabolically, to sodomize execrably, to blaspheme scandalously, to pursue brutally every horrible, dirty and unnatural desire, to hold as precious toads, vipers, lizards and all sorts of poisons; to love a vile-smelling goat, to caress him lovingly, to press against and

\footnotetext{
${ }^{29}$ Diane Purkiss, The Witch in History: Early Modern and Twentieth-Century Representations (London and New York: Routledge, 1996), p. 210

30 'Slut', Oxford English Dictionary, $<$ http://www.oed.com.ezproxy4.lib.le.ac.uk/view/Entry/182346?rskey=WonOs L\&result $=1 \&$ isAdvanced $=$ false\# $\#$ eid $>$ [Accessed June 2011]
}

copulate with him horribly and shamelessly. ${ }^{31}$

Similarly in Middleton's The Witch, nearly all the activities above take place between the witches. Hecate and the other witches are dedicated to the devil either for their own interest or instead for those (the other human characters in the play) who consult with them, resulting in a compact with the devil. They also possess familiar spirits such as toads, bats and cats, and allow these familiar spirits to suck their blood. The pact between a witch and the devil takes place followed by a Sabbath, or some days after, the devil directs the witch to a meeting with the other witches. Rosen describes the differences between making a pact in England and Scotland: 'in England, blood sucked by a "familiar devil" in animal form was the simple and only form of pact till the mid-seventeenth century. In Scotland, he baptized the witch with blood from the mark which he bit or pinched into her flesh'. ${ }^{32}$ The devil always marked the body of the witches with a privy mark. The witches confessed that the devil licked them with his tongue in some secret part of their body before he became the witches' servant. The marks generally were made under the hair in some part of their body and could not easily be found. The witches did not confess until the devil's mark was found, particularly when all their hair was shaven off each part of their body. ${ }^{33}$

The witches were persecuted for heresy if any pact or any physical signs of one were found during their confession. Thus, according to the [C]church, any kind of magic or sorcery was considered as heresy. It was believed that heretics could be men, women or children, but most were women. In early modern England, sorcery was normally identified with heresy. Heresy was associated with demons and with the practise [practice] of using supernatural power to kill instead of giving life. In The Witch, the witches are clearly not innocent characters, since they confess themselves that they have committed crimes. Their untroubled admission of murder, particularly infanticide, pushes the boundaries of the comic mode in which they usually appear. Hecate and her fellow witches are seen to have committed a crime when Hecate says: 'And fetch three ounces of the red-hair'd girl/ I killed last night' (V.ii.55-56). In Macbeth, the witches also appeared to have committed a crime when a witch says: 'Nay, here's three ounces of a red-haired wench' (IV.i.58). Hecate sounds nonchalant in her casual reference, whereas the witch in Macbeth is more sinister. In The Witch, the shock comes from the fact that her reference to (very) recent murder is off-hand; in Macbeth, it seems to me that the horror is in the fact that the 'wench' is reduced to an 'ingredient'. The witches in both plays use a common source as an ingredient in casting spells. Middleton's Hecate talks about infanticides when she procures a charm

\footnotetext{
${ }^{31}$ Cited in Robin Briggs, Witches and Neighbours: The Social and Cultural Context of European Witchcraft (London: HarperCollins, 1996), p. 32.

${ }^{32}$ Barbara Rosen, Witchcraft (London: Edward Arnold, 1969), p. 17.

${ }^{33}$ Ibid., p.194.
} 
to lead Almachildies to a sudden death:

Leave all to me, and my five Sisters, daughter:

It shall be convaid in at Howlott-time

Take yo ${ }^{w}$ no Care; My spirits know their Moments,

Rauen, or Screich-owle never fly by the'dore

but they call in- (I thanck 'em;) and loose not by't

I give 'em Barely, soakd in Infants-Blood

They shall haue Semina, cum Sanguine,

Their gorge crambd full, if they come once to or house.

We are no Niggard. (V.ii.1973-1981)

In making a spell in order to fly into the air, Hecate gives Stadlin the dead body of a child in her abode and instructs him to boil it well and preserve the fat. This is another example of infanticide by the witches:

HECATE, There, take this vn-baptized-Brat:

Boile it: preserve it the ffat:

You know 'tis precious to transfer

Our 'noynted fflesh into the Air, (I.ii.200-203)

Thus we can see that despite the fact that the witches are not seen as innocent creatures since they commit infanticide, they still form a comic part of the play. This is because Middleton's witches seem to be more interested in having sexual relationship with animal familiars and the devil than anything else, see my discussion below of their overt sexual behaviour. In contrast to this, Macbeth's witches commit a crime but form a tragic part of the play.

\subsection{English and Continental Traditions of Witchcraft in Middleton's the Witch}

Although Middleton's The Witch belongs to the English tradition of witchcraft rather than Continental witchcraft, one can also find notable resemblances and similarities with Continental beliefs about witches' behaviour. Therefore, one should take all the characteristics of Middleton's The Witch into consideration such as whether they have familiars or not for their demonic help, the ingredients they use for their charms, the power they claim to have and use against people and animals, their place in the community and several other characteristics.

One of the distinctive evil characteristics of witches in this play is their sexual desire. Middleton uses the idea of sexual desire in the witches for the comic representation of the supernatural in the Jacobean era. It is obvious that Hecate has the role of succubus not incubus especially in the scene mentioned above between she and her son, and in the following scenes when Almachildies consults her:

ALMACHILDIES. Call you theis Witches? they be Tumblers, me-thincks, very flat Tumblers. HECATE. 'tis Almachildes: fresh Blood stirrs in Me the man that I haue lusted to enjoy

I haue had him thrice in Incubus already. (I.ii.393-397)
Almachildies calls the witches 'Tumblers' which means entertainers in the Oxford English Dictionary. ${ }^{34}$ Alongside the ideas of physical agility, there is a sexual connotation here (see 'tumble', v.9a 'To have sexual intercourse with. slang'). ${ }^{35}$ Hecate here implies that she has had sex with a devil in Almachildies' shape. Alternatively, it might also show the audience that Almachildies has been sexually subjugated to the witch Hecate and has a close relationship with her, especially when he accepts Hecate's invitation to dine with her (when he is drunk and brings Hecate a toad to make into a love charm for Amoretta). Moreover, Hecate also reminds Stadlin (another witch) that she is going to have the son of the mayor of Whelplie the next morning:

HECATE. Last night thou got'st the Maior of welplies Son.

I knew him by his black cloake, lyn'd with yellow;

I thinck thou'hast spoiled the youth: hee's but seaventeene,

I'll haue him the next Mounting: away-in.

goe feed the Vessell for the second howre. (I.ii. 217-221)

These examples of Hecate's relationship with the people around her are more evidence of English witch-lore. The English witches are visited by their customers more often than in Continental tradition. The other English witches such as Mother Bombie and the Wise Woman of Hogsdon and the witches in The Late Lancashire Witches are also seen by many characters. However, Harris argues that 'Hecate displays many of the sensational features that were more frequently applied to the European witch than to the English equivalent' ${ }^{36} \mathrm{He}$ argues that Hecate and her fellow witches are creatures of the night, gathering their magic herbs and flying through the air. Hecate and her fellow hags have familiar spirits for demonic aids, such as cats, toads and bats. This feature of having familiars can be found in the traditional form of witch beliefs, in that the witches allow them to suck their blood. In Middleton's The Witch, the witches allow their familiars to suck their blood:

STADLIN. There was a Bat hoong at my lipps three times

as we came through the woods, and dranck her fill. old Puckle saw her. (III.iii.1287-1290)

Hecate also has sex with her animal familiars such as the Cat (I.ii.286-288). Having intercourse with an animal familiar is more representative of the European witch Sabbath rather than the English witch. Gibson states that the blending of demon-lover and animal is from the European Sabbath while there are a 'few English

\footnotetext{
34 'Tumbler', Oxford English Dictionary,

$<$ http://www.oed.com.ezproxy4.lib.le.ac.uk/view/Entry/207355?redirectedFro $\mathrm{m}=$ tumbler\#eid $>$ [Accessed August 2011]

35 'Tumble', Oxford English Dictionary, $<$ http://www.oed.com.ezproxy4.lib.le.ac.uk/view/Entry/207350?rskey=uldVNy \&result $=2 \&$ is Advanced $=$ false\#eid $>$ [Accessed August 2011]

${ }^{36}$ Harris, Night's Black Agents, pp. 81-82.
} 
accusations of sex with man-shaped spirits (for example, the most strange and admirable discoverie of the three Witches of Warboys (London, 1593) or incest (A true and just Recorde (London, 1582))'. She also argues that the cat that appears later might be an unnaturally large animal. ${ }^{37}$ However, Rosen opposes Gibson's idea by arguing that having a familiar was already 'common in popular English witch-belief as a privately-owned devil in animal form' and that a 'witch's pet was indeed proof of her witchcraft'. She also adds that having a familiar led to searches for the teat at which the witch supposedly nourished her familiar and 'this was already the popular English version of the mark, appearing in most trials after 1579 and from then on it was regarded by many judges as most important evidence for the prosecution'. ${ }^{38}$ The Witch is most obviously based on English witchcraft but Middleton clearly adds some characteristics of Continental witches to the play, such as flying at night and sexual desire. I will concentrate on Hecate's familiars later in a section that deals with how familiar scenes would have worked on stage and how Middleton used certain effects for certain actions of the play.

Returning to Hecate's invocation, it is addressed to a list of the names of devils or unearthly creatures, which is also drawn heavily from Scot: 'Urchins, Elves, Hags, Satyrs, Pans, Fawns, Sylvans, Kitty-with-the-candlesticks, Tritons, Centaurs, Dwarfs, Imps, the Spoorn, the Mare, the Man-I'th'-oak, the Hellwain, the Fire-darke, the Puckle! Aab hur hus!'(I.ii.105-9). The last phrase with which Hecate concludes, 'Aab hur hus!' is a traditional charm against toothache, also borrowed from Scot. ${ }^{39}$ Middleton borrowed the names of devils from Scot and the names of two of Hecate's hags, Hellwain and Puckle, are also taken from this list of spirits. Scot combined a mixture of English, European and classical spirits together. Attempting to classify the familiar names, he stated that 'hags are female evil spirits; satyrs, pans, fawns, sylens, or silvans (a kind of satyr or a wood spirit), tritons and centaurs are all humananimal creatures from classical mythology; ... the mare is the nightmare; ... ${ }^{40}$ Scot's and Middleton's use of all these different names for the devil, has the effect of ridiculing all such beliefs regarding what the witches were thought to be doing under any of the above mentioned devilish names. Moreover, Scot's intention in using such devilish vocabulary was to convince his readers of the unreality of such beliefs about witchcraft and magic in early modern England.

Along with the names of spirits, there are also some kinds of magical herbs used in Middleton's The Witch which are borrowed from Scot's the Discovery of Witchcraft such as, 'Chirocineta, adincantida/ Archimedon, marmaritin, calicia' (I.ii.161-2). Bullen notes that

\footnotetext{
${ }^{37}$ Marion Gibson, Witchcraft and Society in England and America,1550-1750

(London: Continuum, 2003), p.101.

${ }^{38}$ Rosen, Witchcraft, p. 23.

${ }^{39}$ The Works of Middleton, ed. by Bullen, p. 372.

40Gibson, Witchcraft and Society in England and America, p. 102.
}

'pythagoras and ademocritus' which are the names of great magical herbs and stones, 'whereof now both the virtue and the things themselves also are unknown'. As Marmaritin, 'whereby spirits might be raised: Archimedon, which would make one bewraie in his sleep all the secrets in his heart'. Moreover, there were other kinds of herbs, such as: Adincantida, Calicia, Meuais, and Chirocineta, 'which had all their seuerall vertues, or rather poisons. ${ }^{41}$ In another scene Hecate names several ingredients which are also borrowed from Scot:

\section{Acontium, frondes populeus, and Soote, yo 'may see that, he looks so back 'th' mouth \\ then Sium, a Charum, Vulgaro too \\ Dentaphillon, the Blood of a flitter-mowse, \\ Solanum Somnificum et Oleum (I.ii.226-230)}

Here, Hecate names several ingredients to Stadlin such as 'mountain parsly, poisonous aconite, or wolf's bane, polar leaves, yellow watercress, myrtle, cinquefoil, bat's blood, deadly nightshade "containing belladonna and with hallucinogenic properties", which were often thought by sceptics to be responsible for the flying fantasies of witches. ${ }^{42}$ These named ingredients are used by the witches to make a kind of ointment in order to ease their flight in the air, and also to make their magical charms. The flying of witches during their Sabbath was popular on stage because it could offer a comic spectacle to the audience. Using the cauldron and the magical ingredients to make an ointment, Middleton's Hecate and Malkin pretend to fly. This scene forms a comic part of the play and thus the play can be called tragicomedy.

\subsection{Tragicomedy}

Before defining tragicomedy, I want to explore why Middleton called his play The Witch, and why he positioned it within the tragicomedy genre. As this thesis has demonstrated throughout, plays about witchcraft and witches were popular in early modern England and, moreover, people were interested in flying witches and their dances. There are several witch scenes in the play, however the witch Hecate is not conspicuously the main character in it, so in calling his play after her, Middleton is drawing attention to one particular aspect of the play rather than the main, tragic elements of its plot in order to heighten its appeal to audiences. John Fletcher, in his The Faithful Shepherdess, defines tragicomedy as,

not so called in respect of mirth and killing, but in respect it wants death, which is enough to make it no tragedy, yet brings some near it, which is enough to make it no comedy, which must be a representation of familiar people, with such kind of trouble as no life be questioned; so that a god is as lawful in this as in a

\footnotetext{
${ }^{41}$ The Works of Middleton, ed. by Bullen, p. 375.

${ }^{42}$ Gibson, Witchcraft and Society in England and America, p. 100.
} 


$$
\text { tragedy, and mean people as in a comedy. }{ }^{43}
$$

Although tragicomedy 'wants death' on stage, there is often an off-stage death in English versions of the genre, as in the case in Middleton's The Witch when Antonio falls to his death as he tries to find Isabella. Some characters are near to 'death' and some others are in danger of being sentenced to death for their crimes. Fletcher's remark on the representation of a supernatural power intervening in the plot as being 'lawful' or legitimate also tallies with this play. The Witch consists of three succeeding plots ranging from the lower-class characters (witches and servants) to the Duke and the Duchess' family. The noble family (perhaps modelled on the Somersets) forms the tragic nucleus of the play but the witches, spirits and servants occupy the comic part of the play.

The tragicomedy of Middleton and Shakespeare typically includes surprises, transgressions and disguises, and supernatural elements also abound, such as witches, goddesses and fairies. As Smith usefully states, 'Jacobean tragicomedy has an "essential comic design" (intrigueridden plots of romantic love) onto which is imposed a "burden of ... tragic implication," of emotional intensity and mental agitation. ${ }^{44}$ The Witch is a hybrid, with some plots dealing with romantic love among the characters as well as other comedic plots. The play reaches a conventionally comic end with the reunion of the two separated lovers, Sebastian and Isabella, although Antonio dies by the end of the play. Hermio announces Antonio's death when he is searching to find Isabella in Fernando's house:

\section{a fearful, vnexpected Accident \\ brought death, to meet his fury: for my Lord entering Fernando's house, like a raisd Tempest, ( $w^{\text {ch }}$ nothing heedes but its owne violent rage) blinded with wrath, and Ielouzie, (which scorne guides) from a falce Trap-dore fell into a depth exceeds a Temples height: which takes into it part of the doongeon, that falls threescore ffaddom vnder the Castle. (V.iii.2057-2065)}

The lord governor is pleased to hear this news and says that Antonio deserves his fate. All the scenes of the play emphasize human weakness and 'all dwell on the tragic irony that defeats human desires, all portray a dark worldless violent perhaps but scarcely less terrifying than the world of The Revenger's Tragedy and Woman Beware Women. ${ }^{45}$ Antonio cannot survive by the end of the play and his adventurous desire results in his own downfall. Human desires are also depicted through the witches on stage. Schoenbaum argues that Middleton's witches are less interested in shaping men's destinies than in satisfying

\footnotetext{
43 John Fletcher, The Works of Beaumont and Fletcher, ed. by George Darley, 2 vols (London: Edward Moxon, 1840), i, 264-287 (p. 264).

${ }^{44}$ Logan \& Smith, The Later Jacobean and Caroline Dramatists, p. 15.

45 Richard Hindry Barker, Thomas Middleton (New York and London: Columbia University Press and Oxford University Press, 1958), p. 92.
}

their own lusts by sleeping with 'visitors or succubi or their own offspring; their escapades reflect the persistent concern with sexuality that is to lead the dramatist, in his mature tragedies, into psychological explorations unattempted by his contemporaries'. ${ }^{46}$ Middleton portrays the witches as creatures who are more interested in sex than anything else. This is one of the dramatic devices that the dramatist uses as a special effect to make the play a tragicomedy.

Middleton does not present and mediate morality to his audience in The Witch. He does not tell us what moral lesson we should draw, and it is remarkable- compared to Shakespeare, for instance - that many fundamentally corrupt and tainted characters not only survive, but thrive at the end of the play. The audience cannot find any perfect examples of chastity and honour in this play. For example, the Duchess plans to kill the Duke and then Almachildies but she is finally pardoned. The plot of two amoral and lewd characters, Francisca and Abberzanes, is neither comedy nor tragedy but a middle mood. This is because their plot is too disreputable to be considered tragedy and too unsociable for comedy. Although they both are from the middle class, they are pardoned by the end of the play. The characters of noble/aristocratic class are given this treatment, but rarely those of the middling classes. Francisca in some ways resembles Bianca in Women Beware Women (1612-1627), who is a mistress first and then becomes the wife of Francisco de' Medici. Abberzanes also resembles Lactantio (nephew of Lord Cardinal of Milan) in More Dissemblers Besides Women (1615) who has an affair with his mistress, Aurelia. The plots of these characters are comedy and tragicomedy too. In these plays, the four characters form parts of similar plots and turn the play into tragicomedy. The tragicomic conventions of this play also stem from Middleton's use of withheld information and surprise. Surprise takes place because some scenes or actions take place offstage without the audience being aware of this. For instance, we suddenly learn that the Duchess is accused of adultery:

GOVERNORE, No, my Sword
shall neuer stayne the virgin-brightnes on't
With blood of an Adulteresse. (V.iii.2144-2146)

However, she denies being an adulteress and losing her honour to Almachildies (V.iii.2147-2150). She rebuffs the accusation of being an adulteress but the audience are not aware of this until this moment because when she blindfolds Almachildies and then takes off the bandage from his eyes, we see the Duchess say: 'say, thou must either die, or kill the duke;/ for one of them thou must do' (III.i.960-961). We are misled here as the audience because some of the actions occur offstage. For instance, the audience does not know whom Almachildies sleeps with while blindfolded because it takes place off-stage. However,

46 Samuel Schoenbaum, 'Middleton's Tragicomedies', Modern Philology, 54 (1956), 7-19 (p. 9). 
Amoretta then announces on-stage that it is a hired prostitute and not the Duchess. Moreover, deceptions occur when actions take place offstage. This stage-whispering (the scene between Amoretta, the Duchess, Almachildies and Florida) can be considered as one of the techniques or devices that Middleton uses, as the audience is not informed about what takes place offstage.

Another device that pushes the play into tragicomedy is the withholding of information and disguising of it until nearly the end of the play in Act 5, scene 1. From the beginning of the play Isabella is not aware that Antonio has misled her with the false report of Sebastian's death in a fight, in order to marry her. However, when Sebastian disguises and names himself 'Celio' to keep Isabella in Fernando's house for a while, Isabella curses Antonio and says she would not find herself in such an unpleasant situation if Sebastian were alive:

Well: well, Sir,

I'll haue that Care, I'll not disease him much, Tread you but lightly: oh, of what grosse falcehood is Mans heart made of! had my first loue liu'd and return'd saffe, he would haue by a light To all Mens Actions, his faith shinde so bright. (IV.ii.1591-1596)

Isabella is being deceived here and (unlike the audience) does not realize that Celio is Sebastian until Act V. iii. Then she expresses her joy and disbelief. This kind of withholding and disguising of information can be seen to adhere to the tragicomic conventions of the play. This ending is found in both forms, tragicomedy and comedy.

Both Middleton and Shakespeare were influenced by the popular beliefs of that time. It is needless to speculate whether they believed such things themselves or not; what we can assert is that they recognized the dramatic potential and popular appeal of using supernatural and mythological characters in their works. By using goddesses Shakespeare gives licence to the audience's imaginations by showing mythical characters as having the same qualities and characteristics as humans. Both forms of supernatural beings - witches and goddesses - are here used to solve the problems of the play as well as categorizing the genre of the play. Shakespeare uses mythical characters such as nymphs, goddesses and fairies to resolve problems in the plots of his plays. The same concept occurs with the witches, but with the added significance that (unlike the classical gods) the idea that witches existed and possessed strange and dark powers had some currency. Middleton's witches are vulgar, ridiculous, ugly, distorted and sexually offensive. They do not harm the other characters, they only excite laughter without causing pain to anyone in the play. Both the creature types used by Middleton and Shakespeare (in his later plays) are supernatural and are used to form the comic element of the play. In addition to this, they included non-supernatural characters as well as illusions -witches, goddesses and nymphs- that refer to the supernatural beliefs of early modern society regarding the existence of superstitious power. The main difference between Middleton's presentation of supernatural power and Shakespeare's is that Middleton shows supernatural effects through technology in such a way as to engage with the audience. In contrast, Shakespeare expresses the supernatural element through words rather than technology.

The popularity of this genre in 1600s-1610s steadily increased. Plays with tragicomedy were fashionable and in high demand, especially at the Court. This was related to the advanced system of elaborate machines and decors which were adapted for staging the miracle effects of the supernatural entities. Not only restricted to Middleton's work, tragicomedy dominated Shakespeare's later plays. The vogue for tragicomedy went into decline in 1640, and the popularity of tragedy came back into fashion afterwards. Blackfriars presented witchcraft in tragicomic modes as witchcraft mania was fading in this period, and the playhouses were more advanced technologically for staging supernatural spectacles of witches.

Along with tragicomedy, one can say that technology and comedy come together in The Witch. I have mentioned the actions of the actors who take part in categorizing the play as tragicomedy and argued that the witches form a comic part of the play, as through their supernatural effects on stage they provide exciting entertainment for the audience, even while more tragic events happen, such as Antonio's death. Thus, the technology and comedy work together in turning the play into a comic spectacle through the visual effects that were provided by the King's Men. In dramatizing these plots, Middleton required special features of the playhouses to stage the supernatural effects of the witches. For example, the spaces of the 'hut', 'heavens' and 'above' are extremely important in staging the witch scenes. With the advanced technical ability of the Blackfriars in adapting more elaborate machines, this made more supernatural effects on stage possible in terms of flying, descending and ascending of the witches and deities.

\subsection{Flight in Middleton's [T]the Witch}

In this section I will focus on the playhouse where The Witch was staged, paying special attention to the witchcraft scenes. Early seventeenth-century and later evidence will also be examined to determine what alterations have been made in stage directions in particular scenes of the supernatural characters. This chapter asks the questions what kind of props, sound effects, and other staging devices (for example, the use of the balcony/ gallery and winch) were needed to stage these supernatural scenes, and how was witchcraft transposed into a theatrical experience. After all, Middleton made full use of the staging resources at his disposal, and this play is as much about spectacle as it is about plot. Using Andrew Gurr's descriptions of the structure of private playhouses, especially Blackfriars, with the players of the King's Men, I will apply it to Middleton's The Witch in order to reveal which parts of the playhouse Middleton employed in his plots. Gurr describes how there was a balcony or gallery (sometimes called the 
'tarras' in the seventeenth century), at the first gallery level in the tiring- house façade. Above the balcony or tarras, there was a cover or 'heavens' supported by two pillars raised up from the stage. ${ }^{47}$ The 'heavens' and the 'hell' (the space under the stage) are religious terms which probably originated in the private houses. ${ }^{48}$ The advantage of the heavens was that it protected the stage from bad weather conditions such as cold and rain, and it also provided a space from which to let things descend down onto the stage.

Upstage, there was a 'hut' or huts which were set on top of the heavens to provide the effects of lightning and thunder. The effects of 'flights' and descending onto the stage were also provided by the 'hut' through the stagehands operating machinery. Private playhouses such as Blackfriars used candles for presenting night scenes. For instance, in the field scene Hecate and her fellow witches enter onto the stage, and she describes the brightness of the moon:

\section{HECATE, The Moone's a Gallant, see how brisk she rides! \\ STADLIN, here's a rich Evening, Heccat. (III.ii.1278- 1280)}

In the indoor playhouses, there was a 'heavens' the underside of which was painted with a moon and stars. ${ }^{49}$ The majority of scenes with the witches take place at night, and the witches here descend again through the hut of the stage. The hut was also used for producing thunder and lightning effects. For example in Shakespeare's Macbeth, the three Weird Sisters meet in thunder and lightning. In Cymbeline, Jupiter also flies down on an eagle through thunder and lightning onto the stage. ${ }^{50}$

The equipment for the flying machines was usually set up in the hut. To ascend and descend from the heavens to the stage, one needed to use a wire or rope to fly down. Some playhouses had more than one hut which controlled the flight of the characters from the stage and the huts had enough space to accommodate the storage of eagles, chariots, cars, thrones and any other necessary equipment used for flights. No contemporary references offer a precise design of the second Blackfriars, but Wickham describes it as a large medieval hall known as the parliament chamber. ${ }^{51}$ Although its precise shape and size are unknown, it has been estimated as having been about 66 feet long and 46 feet wide. In respect of scenic spectacle,

\footnotetext{
${ }^{47}$ Andrew Gurr, the Shakespearean Stage, 1574-1642 (Cambridge: Cambridge University Press, 1970), p. 121.

${ }^{48}$ MacMillin, 'Middleton's Theatres', p. 81.

${ }^{49}$ Gurr, the Shakespearean Stage, p. 121.

${ }^{50}$ The effect of thunder, in both public and private playhouses, was presumably produced by 'bowling heavy balls of stone or iron along wooden troughs, supplemented by rolls on snare drums and kettle drums'. The effect of lightning was probably 'produced by some sort of pyrotechnical device not fully understood'. Irwin Smith, Shakespeare's Blackfriars Playhouse: Its History and Its Design (London: Peter Owen, 1964), p. 144.

${ }^{51}$ Glynne Wickham, 'The Second Blackfriars', in English professional Theatre, 1530-1660, ed. by Glynne Wickham, Herbert Berry, and William Ingram (Cambridge: Cambridge University Press, 2000), pp. 501-504.
}

one can say that the flight of Middleton's Hecate provides evidence that Blackfriars had flying machinery capable of making witches fly.

Concerning the technical possibilities of flying witches on stage, Middleton's witches in Act 3, scene 3 pretend that they can fly and make their journey at night with the help of a magic ointment. This ointment is used here to help the Cat to descend (III.iii.48) and to enable the ascent of both Hecate and Malkin back to the heavens. Reginald Scot asserted the belief that witches rode in the air, and provided evidence attesting to the popularity of this superstition:

How witches are summoned to appear before the devill, of their riding in the aire, of their accompts, of their conference with the devil, of his supplies, and their conference, of their farewel sacrifices: according to Daneus, Psellas. ${ }^{52}$

This extract is about the flight or transvection of witches to the Sabbath or their Covens with the help of the devil. In The Witch, the congregation of the witches and their revelry at Sabbaths are elements of English witch lore but not the transvection of witches. The advanced technology of Blackfriars facilitated the congregation of the witches and their flight on stage. While witchcraft treatises focused on the flying of witches through ointment, the King's Men could stage this supernatural scene by the use of flying machinery. In Act 3, scene 3, the descent of Malkin is covered by Hecate's ointment and the noise of the machinery is covered by the off-stage choir in its turn:

\section{Ther's one comes downe to fetch his dues \\ A kiss, a Coll, a Sip of Blood. \\ And why thou staist so long \\ I muse, I muse. \\ Since the Air's so sweet, and good.}

The same flight scene in Macbeth was performed by the King's Men at the Blackfriars. Scot inserted an aspect of the Continental practice of witchcraft, that is, flying witches, into his demonological treatise. Moreover, he discusses the belief that witches fly through the air with the devil's assistance, and that they become the devil's servants in return for having the power to ride in the air. The devil warns the witches to appear in their assemblies at night, where the devil can understand whom they have slain. The devil leads them to fall dancing and singing and then makes them invisible in the air. The belief that witches needed a kind of ointment to enable them to ride and vanish into the air was very widespread in the early modern period. Scot also includes this belief in his book and states that people believe that witches use ointment for their transportation and other miraculous effects:

Sundry receipts and ointments, made and used for the transportation of witches, and other miraculous effects:

\footnotetext{
${ }^{52}$ Reginald Scot, Scot's Discovery of Witchcraft (1651), 1-227, book III, ch. 3; p. 37.
} 
an instance thereof reported and credited by same that are learned. ${ }^{53}$

Reginald Scot and King James I in their demonological treatises focus on the belief of transporting of witches by the use of ointment and also on the diabolic nature of the witch as depicted in her physical behaviour. The Elizabethan and Jacobean witch on stage was presented as spectacular through her diabolical demeanour, embodying the characteristics mentioned in the learned demonological texts. Thus, the dramatists consciously based their representations on the circulated information about witches, and dramatised into a stage performance the witch's behaviour for entrainment of early modern audiences. However, in Elizabethan theatres, the powers of stage witches were restrained from incorporating the Continental practices of witchcraft, such as transporting the witches, spirits, magicians and goddesses through the air and flight due to the lack of necessary stage machinery. Along with Scot, in his Daemonologie (1597) King James also discussed flying witches and the question of how witches were able to achieve their aerial journey with the aid of their spirits whether above earth or sea:

What are the waies possible, wherby the witches may transport themselues to places far distant, And what ar impossible \& mere illusions of Sathan And the reasons therof. ${ }^{54}$

The above extract and chapter heading says the belief that witches transport themselves from one place to another may be impossible. In The Witch, Hecate's minion, Stadlin seems to raise an actual storm, making hail and thunder, which originated from folk-tales since witches were believed to wreck ships by creating storms and thunder. One might think by way of parallel of the roughly contemporary play The Tempest, in which Prospero, the usurped Duke of Milan, as a magician conjures up a storm in order to cause the ship to run a ground. Both features of witches, such as, flying and sailing can be seen in Middleton's witches. James VI argued that witches were also carried swiftly from one place to another by the force of their spirit, which is their conductor, either above the earth or above the sea. In his opinion, witches are merely visible to each other while they are in the air but not to others. Middleton gives the audience some sense of the witches' role: they work as agents and are merely seen when they are busy fulfilling the wishes of the other human characters. Real human characters can exist everywhere but a 'witch' can only exist during the Sabbath when meeting with other witches.

We have seen that it was not only historians and monarchs who wrote about the witches' power and how they transported themselves, but playwrights also portrayed their transportation through speaking about flight in words

\footnotetext{
${ }^{53}$ Reginald Scot, Scot's Discovery of Witchcraft (1651), 1-227, book X, ch. 8; p 135.

${ }^{54}$ Ibid, book II, ch. 4; p. 37-8.
}

or through stage effect. Middleton dramatises both the aids of ointment and spirit to help the transportation of Hecate. Similarly, ointment is also used in Jonson's The Masque of Queens for the transportation of the witches. One can find a similar theatrical and magical effect in both plays, The Witch and The Masque of Queens, when Hecate and Ate use the word 'anoint' to go riding. In The Witch, the result of anointment by Hecate helps the descent of the Cat, as she descends before she flies: 'I will but 'noint, and then I mount' (III.iii. 1342-1343). Similarly, Ate also anoints in The Masque of Queens before start flying:

Sisters, stay, we want our Dame;

Call upon her by name,

And the charm we use to say,

That she quickly anoint, and come away. (40-4) ${ }^{55}$

In both plays anointments are used to make scenic spectacles of transporting characters from the stage to the heavens or vice versa. For instance, Hecate is still on stage and anoints the Cat which helps to cause her to ascend back to the heavens: ' $\mathrm{O}$, art thou come?/What news, what news?' (III.iii.1349-1350). ${ }^{56}$ As Wickham states, 'from a theatrical standpoint this scene is cleverly thought out, eminently practical, and highly spectacular'. He also adds that 'verbally, visually, and no doubt musically, it meets the requirements of a second variation upon the original theme which has as its object the motorization of Hecate' ${ }^{57}$ Both the music and Hecate, through the visual spectacle of her flight to the heavens, are intended to impress the audience. The aerial journey of the witches and their comic activities are shown through technology and flying machinery. The witch dance and songs can be considered as primarily intended to provide enjoyable entertainment for the audience. During the Jacobean period, the managers of private playhouses encountered a newly elite audience which required and was interested in musical dances and songs. Theatre gave great consideration to the adoption of new instruments and machines at the Blackfriars in order to impress the audience. Middleton used the technology of the stage to satisfy public interest in witcheraft, and he did not only intend to present witches as theatrical characters but also wanted the audience to engage imaginatively with witches and to play with their fears. In addition to this, he also used technology to show 'supernatural' effects to those who were curious about magic.

Stage direction is important here in showing the entrances of exits of Hecate and Makin in Malone MS 12 compared to the modern editions. To solve deficiencies in stage directions, the modern editors use brackets to identify dubious action. To some extent, the use of brackets by the

\footnotetext{
${ }^{55}$ Ben Jonson, The Works of Ben Jonson, ed. by Barry Cornwall (London: Routledge, 1859 ), p. 567.

${ }^{56}$ Wilson, The Witch, p. 58.

57 Glynne Wickham, 'To Fly Not To Fly?' The Problem of Hecate in Shakespeare's "Macbeth"' in Essays on Drama and Theatre, ed. by Benjamin Hunningher (Amsterdam: Baarn, 1973), pp. 17-82 (p. 178).
} 
modern editors is to indicate a matter of individual interpretation for the deficient stage directions. Some early modern dramatic texts gave very few stage directions in their texts even at the entrances and exits of the actors. Therefore, the modern editors address their speech and gestures in square brackets to show the author's intention. I mentioned earlier that Malkin and Hecate 'fly' (Act 3, scene 3) in Malone MS 12 and that the stage direction is:

"A Spirit like a Cat descends" and Hecate "Going vp" 58

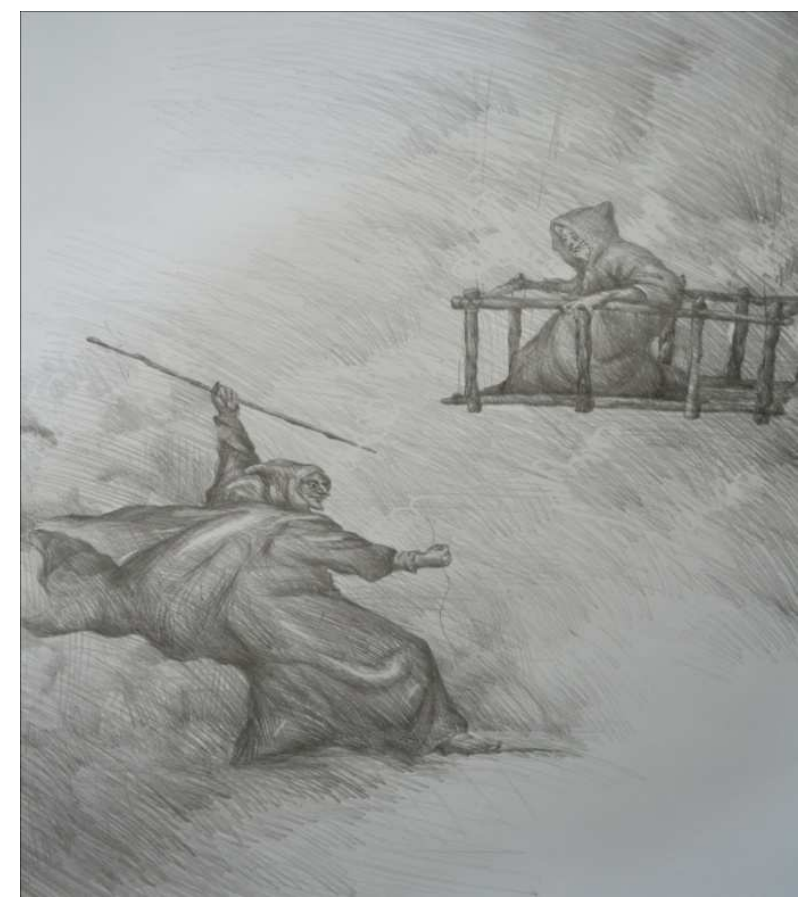

Fig 1. Malkin descends in the lifting machine onto the stage (III.iii.13441346)

Crane did not put stage directions in brackets when he transcribed The Witch. Modern editors do not actually add any words to the above original stage direction. Some put it into brackets, while others do not. O'Connor does not put the stage direction in brackets when Malkin descends: $A$ spirit like a cat descends (see fig. 1) but she does when Hecate ascends above: (going up [with Cat]) (see fig. 2). ${ }^{59}$ However, modern editors use the same stage direction that Malkin 'descends', but in brackets. Dyce, Bullen and Havelock use square brackets in which to put stage directions:

$$
\begin{array}{r}
\text { '[A Spirit like a cat descends]' and Hecate '[going } \\
\text { up],60 }
\end{array}
$$

\footnotetext{
${ }^{58}$ Middleton, The Witch: A Tragi-Coomodie, p. 43.

${ }^{59}$ O’Connor, 'The Witch', p.1152.

${ }^{60}$ Middleton, The Works of Thomas Middleton, ed. by A. H. Bullen, p.416; Havelock Ellis, Thomas Middleton: The Best Plays of The Old Dramatists (London: Viizetelly \& Co., 1890), 115-195 (p. 166); Thomas Middleton, The Works of Thomas Middleton, now First Collected: with some account of the author, and notes in five volumes, ed. by Alexander Dyce, 5 vols ( London: E.
}

Corbin and Sedge use round brackets with the name of the Cat in square brackets:

'([Malkin], a Spirit like a cat descends)' and Hecate '(Going up [with Malkin]) $)^{, 61}$

What is significant here is that in all the above stage directions the Cat 'descends' rather than walking onto the stage. The modern editors have not changed the original stage directions, which were provided by Ralph Crane, of the supernatural characters in The Witch. Corbin and Sedge distinguish the song, 'Come away, Come away', by layout and an italic script which is similar to that of MS Malone 12. When Hecate enters, she is always accompanied by 'five sisters', all of whom ascend the stage except Hecate:

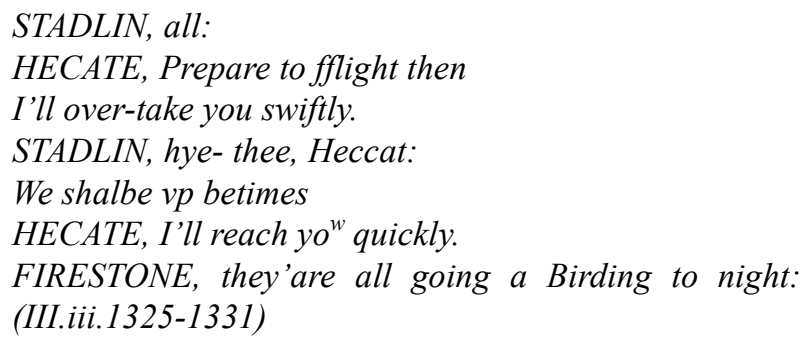

It seems that all of the witches ascend, leaving only Hecate on the stage with Firestone to make the incantation. Here, one can note that an image of demon-assisted flight is presented by Middleton since he shows us the manifestations of Hecate's aerial power in her ability to fly with her spirit. Cox advocates editions which explicate the performance, but writes a note and leaves the text as it is:

my suggestion is that editors reduce sharply or even eliminate completely the stage directions they add to early texts in place of stage directions in the text, this practice outlines staging options in the commentary notes, thus leaving text free of editorial interventions where stage directions are concerned while giving readers enough information to imagine various solutions to staging. ${ }^{62}$

\footnotetext{
Lumley, 1840), iii, 245-335 (p. 304); Wilson, The Witch, p. 58.

${ }^{61}$ Corbin and Sedge, Three Jacobean Witchcraft Plays, p. 121.

${ }^{62}$ John D. Cox, 'Open Stage, Open Page? Editing Stage Directions in Early Dramatic Texts', in Textual Performances: The Modern Reproduction of Shakespeare's Drama, eds. Erne and Kidnie (Cambridge: Cambridge University Press, 2004), p. 178.
} 


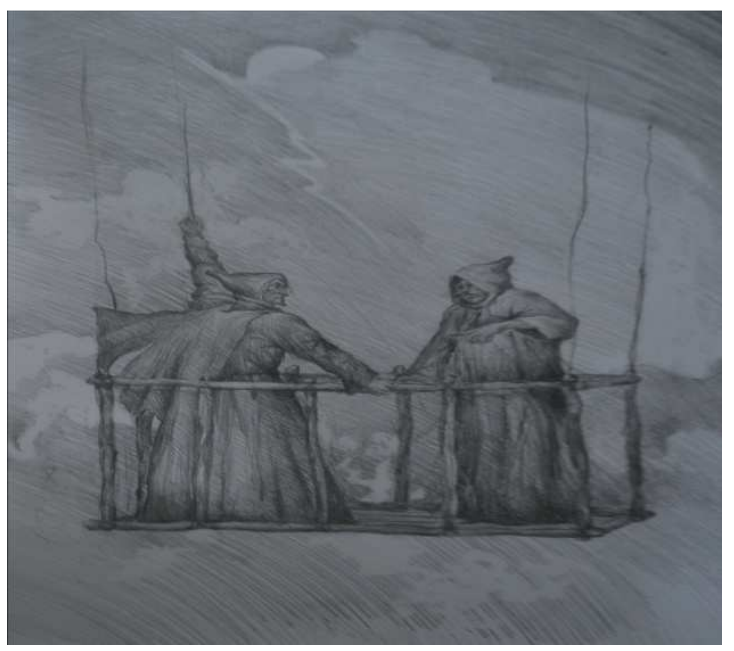

Fig 2. Hecate flies with the Cat (the one on the right) upstage (III.iii.1357-1371)

In my opinion, the editors add stage directions to the early texts in order for readers to visualize what they take to be deficient stage directions, if that addition does not distort the dramatist's intentions. This is why some of the stage directions of early modern texts are written by the scrivener or members of the theatre companies. If not, modern editors add the stage directions in square brackets in order to identify dubious action. Furthermore, modern editors also altered stage directions because of the major changes in the technological progression of theatre. Stage directions in witchcraft plays either in the early texts or in the modern editions tell a narrative of the changing dramatic styles of a certain period.

\subsection{Flying in other Plays of the Period: Shakespeare's Cymbeline and the Tempest}

Malkin's descent and the ascent of Hecate resemble the descent scenes of Jupiter in Shakespeare's Cymbeline, and Juno in The Tempest. Malkin, Jupiter, and Juno all descend from above and the structure of these scenes matches the arrangements at the Blackfriars playhouse. Descents and ascents of deities from the stage heaven, as Gurr states, were matters of spectacle and he is probably right to assert that 'the earlier plays tended to allow their gods to walk on like any mortal; the first of Shakespeare's gods to fly in was Jupiter on his eagle in Cymbeline'. ${ }^{63}$ In Cymbeline, Posthumus is surrounded by the ghosts of his family and Jupiter flies down on an eagle through thunder and lightning onto the stage:

\section{JUPITER.}

No more, you petty spirits of region low,

Offend our hearing. Hush! How dare you ghosts

Accuse the thunder, whose bolt, you know, Sky-planted, batters all rebelling coasts? (V.iv.62-67) ${ }^{64}$

\footnotetext{
${ }^{63}$ Andrew Gurr, The Shakespearean Stage: 1574-1642, $2^{\text {nd }}$ ed. (Cambridge: Cambridge University Press, 1980), p. 174.

${ }^{64}$ William Shakespeare, Cymbeline, ed. by Richard Hosley (New York and
}

In this mini-drama within Cymbeline Shakespeare conveys the powerful theatrical effect of taking the audience inside the dream of Posthumus. Jupiter appears to the audience at the balcony of the stage, and through his powerful speech tries to show the ghosts of Posthumus's family that their sufferings are not insignificant. Before ascending into the heavens, Jupiter gives the ghosts a tablet which they lay upon Posthumus's breast: 'This tablet lay upon his breast, wherein/ Our pleasure his full fortune doth confine' (V.iv.78-79) ${ }^{65}$. This is followed by the ghosts thanking him before they vanish and Posthumus awakes up.

Cymbeline was not entered in the Stationers' Register, and not printed until $1623 .^{66}$ The same stage direction that Jupiter 'descends' in thunder and lightning is used by both early modern and modern editors. Jupiter descends in the First Folio, likewise in the modern editions. ${ }^{67}$ Thus, modern editors do not make any changes in this stage direction. The only difference is that 'descend' may not always mean 'descend' onto the stage in practice, but only in print. The stage direction to 'descend' has a less obvious meaning in early modern editions, normally signifying that the character in question is suspended in mid-air. However, the direction to 'descend' in modern editions means 'descends' onto the stage, not only in printed editions, but in theatrical practice. Galloway argues that Shakespeare's Cymbeline calls for an elaborate descent when Jupiter descends to the stage. He also argues that 'there is some evidence for elaborate apparatus to 'fly' actors and large properties in the Italian theatre of the period, evidence for its use in the English there is mearge'. ${ }^{68}$ Both the masquelike theophany at the end and the descent of Jupiter, Rowse argues, 'would have been for Blackfriars with its more elaborate scenic devices'. ${ }^{69}$ Stern argues that the descent

Toronto: The New American Library; London: The New English Library Limited, 1968), p. 153

${ }^{65}$ Ibid., p. 154.

66Shakespeare, William, The dramatic writings of Will. Shakspere, with the notes of all the various commentators; printed complete from the best editions of Sam. Johnson and Geo. Steevens, p.374.

${ }^{67}$ See Jupiter's descent in the modern editions in: The Oxford Shakespeare: The Complete Works, 2nd ed, by Taylor and Wells (2005), p.1213. The Works of William Shakespeare, ed. by Irving and Marshall (1890), vii, p. 137 (V.iv.92). Shakespeare in Twenty Volumes: Pericles Cymbeline, ed. by Lee, 7 vols (V.iv.92). The Complete Oxford Shakespeare: Comedies, ed. by Wells and Taylor, 2 vols (London: Oxford University Press, 1987), p. 949. The Works of Shakespeare, ed. by C. H. Herford, 10 vols (London: Macmillan, 1899), iv, p. 237. The Works of Shakespeare: Cymbeline, ed. by Nosworthy (London: Methuen, 1955), p. 167. The Complete Work of Shakespeare (Oxford: The Shakespeare Head Press, 1934), p. 1093. The Works of William Shakespeare, ed. by William George Clark and William Aldis Wright, 9 vols (London: Macmillan, 1866), p. 279. The Complete Works of Shakespeare, ed. by Cornwall, 2 vols (London: The London Printing and Publishing Company, [1875]), p. 244. The Complete Works of Shakespeare: including a bibliography and general Introduction, Glossary and Index of Characters, ed. by Charles Jasper Sisson (London: Odhams, 1953), (p.1199). The Annotated Shakespeare: Complete Works Illustrated, ed. by A. L. Rowse (London: Orbis Books, 1978), iii, pp. 724-795 (p. 784).

${ }^{68}$ David Galloway, The Elizabethan Theatre III (Canada: The Macmillan Company of Canada Limited, 1973), pp. (10-11).

${ }^{69}$ The Annotated Shakespeare: Complete Works Illustrated ed. A. L. Rowse, p. 
scene of Jupiter from heaven on the back of an eagle and the riding prophecy he gives, 'mark a turning point in the play, as does Juno's heavenly entrance bless the marriage of Ferdinand and Miranda in The Tempest' ${ }^{70}$

One can apply the same assumption to Juno in The Tempest. ${ }^{71}$ Juno also 'descends' in the Folio, but this does not necessarily mean that she 'descends' to the stage in practice, but only in print. Juno might 'descend' or 'enter' in modern editions. Similarly some modern editors, e.g. the new Variorum edition of Shakespeare, use the same stage direction that Juno 'descends'. ${ }^{72}$ However, Juno simply 'enters', and does not 'descend' (IV.i.105), which is in opposition to the lines 'her peacocks fly amain:/ Approach, rich Ceres, her to entertain' (IV.i.73-4). ${ }^{73}$

Ralph Crane was probably responsible for the rewriting of Shakespeare's Cymbeline and The Tempest. His job was not only to copy the text, but as a scribe, his job was to 'make sense out of a confusing script, and that will have included added more punctuation, and perhaps, supplying obviously missing stage directions, such as exits'. ${ }^{74}$ The printed play that Crane transcribed can easily be identified since he 'massed' or gathered all entrances at the top of the scene'. ${ }^{75}$ Howard-Hill argues that massed entrances can be found in the stage directions of the five Folio comedies which are Two Gentlemen of Verona, Merry Wives of Windsor but not in The Tempest and Measure for Measure. The stage directions in The Tempest are more extensive and descriptive. $^{76}$

\footnotetext{
724.

${ }^{70}$ Tiffany Stern, Making Shakespeare: From Stage to Page (London and New York: Routledge, 2004), p. 5.

${ }^{71}$ The Tempest is written in late 1610 and no records show its performance at the Globe but it was staged at the Banqueting House in 1611. However, Righter argues that it had been acted at Blackfriars with success as this theatre well equipped to provide the play with spectacle, stage machinery, music and atmosphere. William Shakespeare: The Tempest, ed. by Anne Righter (Harmondsworth: Penguin, 1968), p. 23.

${ }^{72}$ The Tempest, ed. by Horace Howard Furness, 9 vols (London: J. B. Lippincott, 1892), p. 204. The Arden Shakespeare: The Tempest, ed. by Virginia Mason Vaughan and Alden T. Vaughan, third series (London: Thomas Nelson, 1999), p. 248. The Tempest, ed. by Frank Kermode, $1^{\text {st }}$ series (London: Methuen, 1954), p. 98. The Tempest, ed. by Virginia Mason Vaughan and Alden T. Vaughan, $2^{\text {nd }}$ series (London: Arden Shakespeare, 2011), p. 270. William Shakespeare: The Tempest, ed. by Righter, p. 117. In both The Oxford Shakespeare: The Complete Works (2005) and William Shakespeare: The Complete Works (1988), ed. by Taylor and Wells, the stage direction is Juno [appears in the air] then [Music. Juno descends to the stage] (IV.i.72.101).

${ }^{73}$ The Works of William Shakespeare: The Tempest, ed. by Morton Luce, $4^{\text {th }}$ ed. (London: Methuen, 1938). The Dramatic Works of William Shakespeare, ed. by S. W. Singer, 10 vols (London: George Bell and Sons, 1884), i, p. ${ }^{63}$ The Works of Shakespeare, ed. by Howard Staunton, 3 vols (London: Warne \& Routledge, 1864), p. 33. The Works of Shakespeare, ed. by C. H. Herford, 10 vols (London: Macmillan, 1899), iv, p. 473. The Complete Work of William Shakespeare (Oxford: The Shakespeare Head Press, 1934), pp. 1153. The Complete Works of Shakespeare, ed. by Cornwall, p. 25. The Complete Works of Shakespeare: including a bibliography and general Introduction, Glossary and Index of Characters, ed. by Charles Jasper Sisson (London: Odhams, 1953), (pp. 31-33).

${ }^{74}$ Stern, Making Shakespeare: From Stage to Page, p. 143.

${ }^{75}$ Ibid., p. 143.

${ }^{76}$ T. H. Howard-Hill, Ralph Crane and Some Shakespeare First Folio Comedies (Charlottesville, 1972), p. 79.
}

The descriptive stage directions of The Tempest were amplified by Crane, who transcribed the manuscript copy used by the printer. ${ }^{77}$ According to Crane's stage direction, Ariel simply 'enters' in the Folio. However, modern editors like Taylor and Wells change the stage direction: 'Ariel [descends] like a harpy'. ${ }^{78}$ They put 'descend' in brackets which indicates that it represents their interpretation of the deficient stage directions. In other words, they change the stage direction and place it in brackets to indicate the author's intention which might not be very clear in its original text.

Harris argues that Ariel 'adopts the form of Harpy but behaves in a Fury-like manner when he assails the consciences of the 'three men of sin' in Act 3, scene 3'. ${ }^{79}$ Adams identifies that 'flight' is not mentioned when Ariel simply 'enters' in the Folio stage directions, but Ariel later 'descends' which can be considered as the first 'free flight' in the history of the English public theatre. Thereafter, actors can 'fly' down from the heavens without any other apparatus than some sort of belt or harness (concealed beneath their costumes?) to which a wire was attached'.

However, Juno descends with Ceres dressed as peacocks. Ceres apparently descends before Juno when she says: 'Great Juno comes; I know her by gait' (IV.i.102) ${ }^{81}$. Then Juno descends to the stage in time to the music and starts singing: 'Honour, riches, marriage-blessing' (IV.i.105-9). Jowett argues that Juno is lowered down on wires in a chariot and later perhaps Juno and Ceres together are 'rapidly pulled up to the heavens' when the spirits vanish. According to Jowett, Juno is lowered down to a 'stationary position in mid air' which is called 'the convention of floating deity'. Orgel assumes that Juno descends through adds a chariot in his stage directions. ${ }^{82}$ After Juno and Ceres are joined, they sing: 'Earth's increase, and foison plenty' (IV.i.110-17). Prospero (a magician) tries to arrange an entertainment for the forthcoming marriage of his daugther Miranda and Fernando (Alonso's son) through using three entertainers (spirits) in the shape of deities: Juno, queen of the gods, and Ceres and Iris who are goddesses of agriculture and of the rainbow. The spirits sing for the couple and then nymphs with reapers descend upon the Island, situated in the balcony, to dance with them.

\footnotetext{
${ }^{77}$ Frank Kermode, 'The Tempest', in The Arden Shakespeare: Complete Works, ed. by Richard Proudfoot, Ann Thompson and David Scott Kastan, $3^{\text {rd }}$ series (Surrey: Nelson and Sons Ltd., 1998), pp. 1069-1093 (p. 1069).

${ }^{78}$ In both The Oxford Shakespeare: The Complete Works (2005), and William Shakespeare: The Complete Works (1988), ed. by Taylor and Wells, pp. (1236, 1182).

${ }^{79}$ Anthony Harris, Night's Black Agents: Witchcraft and Magic in Seventeenthcentury English Drama (Manchester: Manchester University Press, 1980), p. 36.

${ }^{80}$ John Cranford Adams, The Globe Playhouse: Its design and Equipment, $2^{\text {nd }}$ ed. (New York: Barnes \& Noble, 1961), p. 339.

${ }^{81}$ William Shakespeare, The Tempest, ed. by Robert Langbaum (New York: The New American Library; London: The New English Library Limited, 1964), p. 101.

${ }^{82}$ John Jowett, 'New Created Creatures: Ralph Crane and the Stage Directions in the Tempest', Shakespeare Survey, ed. by Stanley Wells (Cambridge: Cambridge University Press, 1983), xxxvi, pp. 107-120 (p. 116).
} 
The spirits pretend to be dogs and wear huge masks, before Prospero and Ariel set them to hunt Stefano, Trinculo and Caliban. After completing her descent, Juno flies back into the air to supervise the dance of the spirits and nymphs. When they finish their dance, the spirits and nymphs vanish in the pageant with a strange and confused noise on the stage.

Between 1599 and 1642, plays that had a large number of props and props which were large in size. The descent and ascent of actors from the stage to the upper stage might not have all required flying machinery but instead used moveable staircases. The effect of this device of transporting the supernatural entities, such as Malkin, Jupiter, Ariel, Juno and Ceres, can be seen as one of the most powerful dramatic effects, besides the other techniques such as withholding information, masques and disguises, which form the genre of the play. Thus their action of descending and ascending create a kind of scenic spectacle intended to amuse the audience. This is because this device works in the comic part of the play to alight and fly the entertainers (spirits) back into the air to supervise the dance of the spirits and nymphs.

Supernatural entities, especially witches, are a subject of pantomime in the Restoration revivals and they operate as a dramatic device of entertainment and fantasy. The Tempest was also adapted by Davenant and Dryden in 1667 and again revived as an opera by Thomas Shadwell in $1674 .^{83}$ Shadwell's version was itself revived several times in the beginning of the seventeenth century. After their alterations to these plays, witches and spirits flew on stage and the spectators were entertained by the new visual spectacle presented by these supernatural abilities. These plays and its adaptations were revived to amuse the contemporary audience and to cater to audience tastes for entertaining spectacle. As farcical plays, they were popular hits at that time and were sure-fire successes in the theatre markets of the second half of the seventeenth century.

In later editions, modern editors also altered stage directions for the supernatural characters in relation to their entrances and exits. It is clear in The Tempest, (Act 3, scene 3 ), that Ariel like a harpy flies down from the heavens to the stage in thunder and lightning and later ascends by flying back. He claps his wings upon the table and then vanishes in thunder. However, Juno's descent is different from Ariel's because her car is seen in the sky before her descent to the stage begins. Juno appears when she is on foot and alights from the car at lines 101-102. The audience can see that the car still remains on the ground after discharging its passenger, Juno, from the heaven to the stage. The car is left on stage because, after this scene, the nymphs and reapers make a graceful dance and vanish in the pageant with a hollow and strange noise (IV.i.141).

\footnotetext{
${ }^{83}$ Christopher Spencer, Five Restoration Adaptations of Shakespeare (Urbana: University of Illinois Press, 1965), pp.17-20. See also Jean I. Marsden, 'Spectacle, horror, and Pathos', in The Cambridge Companion to English Restoration Theatre, ed. by Deborah Payne Fisk (Cambridge: Cambridge University Press, 2000), pp. 174-190 (p. 189).
}

Thus, the car has a double use, first allowing Juno to descend and then the spirits to ascend to the heaven. In short, the car was the most attractive effect used for celestial flight in some Renaissance plays and here the car is especially used for scenic flight of Jupiter and Ariel. Sometimes, a vehicle or chariot was used for celestial flight of the goddesses and witches in order to simulate the imagined events in the mind of the audience. The flights in the majority of contemporary plays merely called for music and song while the players, spirits or witches descended and ascended. For performing flights scenes in the theatres, there were devices which supplied visual effects to the audience such as, the car and chariot, which held around two actors at a time.

In conclusion, the majority of the plays that incorporated flights were performed at the Blackfriars. Shakespeare's Cymbeline and The Tempest were staged at the Globe for a long time. According to Dr Simon Forman's description of the revival of Macbeth at the Globe before 1611, there was not any mention of Hecate or of any witch that flew. Soon after, however, Shakespeare himself had already written scenes requiring Jove to ride an eagle in Cymbeline and Ariel to fly in The Tempest. Wickham argues that the Hecate scene was added to Macbeth shortly afterwards when Shakespeare had retired to Stratford. ${ }^{84}$ Middleton knew that the King's Men employed instrumentalists to provide musical intermission before and during performances, that is why he wrote The Witch to be staged at the Blackfriars. Therefore, shortly after Middleton's initiative, there was nothing left to prevent the King's Men from applying the songs and dance to a subsequent revival of Macbeth. ${ }^{85}$

The Children of the Chapel Royal first used the floor traps in some plays. The King's Men also used floor traps under the stage after the Children, but still the Children were the pioneers. The traps numbered either two or four, were small or long and were located in the mid-stage platform, on the corner of the stage, and sometimes under the inner stage. Generally, traps were large enough to hold four people and had a rectangle shape. Traps in the midstage helped to allow actors to ascend up from under the stage, while traps under the upper inner stage helped to make players 'disappear' into the air in mist. In Middleton's The Witch, Hecate needs to ascend and joins in singing with the other witches in the air. If The Witch was staged before the King's Men took over Blackfriars, Hecate might have ascended by a trap to the upper stage: '[ going up] Now I go, now I fly’ (III.iii.60). ${ }^{86}$ Again, floor traps were used during the charm song about a vessel when Hecate calls her fellow witches: HECATE. 'Come, my sweet sisters; let the air strike our tune,/ Whilst we show

\footnotetext{
${ }^{84}$ Glynne Wickham, 'To Fly Not To Fly? ‘, p. 180. See also Bernard Beckerman, Shakespeare at the Globe, 1599-1609 (New York: Macmillan, 1962), pp. 93-94.

${ }^{85}$ Ibid., p. 179.

${ }^{86}$ Thomas Middleton, The Works of Middleton, ed. by Bullen, p. 417.
} 
reverence to yond peeping moon' (V.ii.84-5). ${ }^{87}$ In both extracts, it seems Hecate goes up through the mid-stage trap and disappears with her fellow witches into the air through the trap that is located under the upper inner stage. Traps may also have been used as a ladder, for instance in The Tempest (I.i) when the mariners enter wet and climb to the deck against a backdrop of thunder and lightning.

In the very beginning of The Witch, the audience sees a banquet in the house of the Lord Governor, but the same stage space is then changed into the abode of Hecate. The actors had double roles and the boy actors had female roles as well. All of the theatrical devices and effects mentioned here required a differentiation to be made between the realistic theatre, that is the platform stage and fictional space, and between the characters and actors of the play. There is no doubt the King's Men could stage the performances of the supernatural entities successfully after they took over Blackfriars and adopted flying machinery for the supernatural effects. It can be argued that public demands made the King's Men add and develop supernatural effects to most of their plays after they performed The Witch. Moreover, this was also a product of the audience's receptiveness to the supernatural spectacle of witchcraft taking place on the stage: such a display must have made them wonder whether witches could fly and how they were able to. It can be argued that audiences were very interested in the supernatural effects and comic spectacle. The playwrights presented the supernatural power through technology both to entertain the audience and to engage with debates about witches' capabilities. The Blackfriars was technically more sophisticated in terms of ability to stage the visual spectacle of the plays. Its technical devices seemed to be designed in order to draw the attention of the audience. In addition to this, at Blackfriars it was not only music and songs that were performed by the King's Men but also short concerts before the plays started. Basically music and songs performed at the Blackfriars were used in pauses between the actions and to increase the emotion of the actions from the stage to the audience. However, the King's Men Company used fewer songs and music at the Globe in comparison to the Children at Blackfriars. Having performed lots of singing and dancing in the witch plays, the King's Men offered a new genre style, tragicomedy, to its Blackfriars audience, and these comical spectacles in the witch scenes drew the attention of the audience extremely successfully.

\section{References}

[1] Adams, John Cranford, The Globe Playhouse: Its design and Equipment, $2^{\text {nd }}$ ed. (New York: Barnes \& Noble, 1961)

[2] Adams, Joseph Quincy, Shakespearean Playhouses: A History of English Theatres from the Beginning to the
Restoration (Gloucester: Peter Smith, 1960)

[3] Barker, Richard Hindry, Thomas Middleton (New York and London: Columbia University Press and Oxford University Press, 1958)

[4] Beckerman, Bernard, Shakespeare at the Globe, 1599-1609 (New York: Macmillan, 1962)

[5] Bradley, A.C. Shakespearean Tragedy (New York: Palgrave, 1992)

[6] Briggs, K. M. , Pale Hecate's Team: an Examination of the Beliefs on Witchcraft and Magic among Shakespeare's Contemporaries and His Immediate Successors (London: Routledge and Kegan Paul, 1962)

[7] Briggs, Robin, Witches and Neighbours: The Social and Cultural Context of European Witchcraft (London: HarperCollins, 1996)

[8] Corbin, Peter and Douglas Sedge, Three Jacobean Witchcraft Plays: The Tragedy Sophonisba, The Witch, The Witch of Edmonton (Manchester and New York: Manchester University Press, 1986)

[9] Cox, John D., 'Open Stage, Open Page? Editing Stage Directions in Early Dramatic Texts', in Textual Performances: The Modern Reproduction of Shakespeare's Drama, eds. Erne and Kidnie (Cambridge: Cambridge University Press, 2004)

[10] Donovan, Frank Robert, Never on a Broomstick (Harrisburg, PA: Stackpole Books, 1971)

[11] Ellis, Havelock, Thomas Middleton: The Best Plays of The Old Dramatists (London: Viizetelly \& Co., 1890)

[12] Fletcher, John, The Works of Beaumont and Fletcher, ed. by George Darley, 2 vols (London: Edward Moxon, 1840), i

[13] Galloway, David, The Elizabethan Theatre III (Canada: The Macmillan Company of Canada Limited, 1973)

[14] Gibson, Marion, Witchcraft and Society in England and America, 1550-1750 (London: Continuum, 2003)

[15] Gurr, Andrew, The Shakespearean Stage 1574-1642 (Cambridge: Cambridge University Press, 1970)

[16] The Shakespearean Stage: 1574-1642, $2^{\text {nd }}$ ed. (Cambridge: Cambridge University Press, 1980)

[17] Harris, Anthony, Night's Black Agents: Witchcraft and Magic in Seventeenth-century English Drama (Manchester: Manchester University Press, 1980)

[18] Howard-Hill, T. H., Ralph Crane and Some Shakespeare First Folio Comedies (Charlottesville, 1972).

[19] Johnson, Samuel and George Steevens, William Shakespeare: in Twenty-One Volumes(London: 1813), ii

[20] Jonson, Ben, The Works of Ben Jonson, ed. by Barry Cornwall (London: Routledge, 1859 )

[21] Jowett, John, 'From Many of Your Companies: Middleton's Early Readers', in A Companion to the Collected Works: Thomas Middleton and Early Modern Textual Culture, ed. by Gary Taylor and John Lavagnino (Oxford: Clarendon Press, 2007), pp. 286-327

\footnotetext{
${ }^{87}$ Ibid., p. 446.
} 
[22] 'New Created Creatures: Ralph Crane and the Stage Directions in The Tempest', Shakespeare Survey, ed. by Stanley Wells (Cambridge: Cambridge University Press, 1983), xxxvi, pp. 107-120

[23] Kermode, Frank, 'The Tempest', in The Arden Shakespeare: Complete Works, ed. by Richard Proudfoot, Ann Thompson and David Scott Kastan, ${ }^{\text {rd }}$ series (Surrey: Nelson and Sons Ltd., 1998), pp. 1069-1093

[24] Logan, Terence P. \& Denzell S. Smith, The Popular School: A Survey and Bibliography of Recent Studies in English Renaissance Drama (Lincoln: University of Nebraska, 1975)

[25] Marsden, Jean I., 'Spectacle, horror, and Pathos', in The Cambridge Companion to English Restoration Theatre, ed. by Deborah Payne Fisk (Cambridge: Cambridge University Press, 2000), pp. 174-190

[26] McMillin, Scott, 'Middleton's Theatres', in Thomas Middleton: the Collected Works, ed. by Gary Taylor and John Lavagnino (Oxford: Clarendon Press, 2007), pp. 74-87

[27] Middleton, Thomas, The Works of Thomas Middleton, ed. by A. H. Bullen, 8 vols (New York: AMS press INC, 1964), V

[28] The Witch: A Tragi-coomodie, Called the Witch (Louvain: Librairie: Ch. Uystpruyst, 1945)

[29] The Works of Thomas Middleton, now First Collected: with some account of the author, and notes in five volumes, ed. by Alexander Dyce, 5 vols (London: E. Lumley, 1840), iii

[30] Muir, Kenneth, The Arden Shakespeare: Macbeth (London: Methuen, 1951)

[31] O'Connor, Marion, 'The Witch', in Thomas Middleton: The Collected Works, ed. by Taylor and Lavagnino (Oxford: Oxford University Press, 2007), pp. 1124-64

[32] Orgel, Stephen, 'A Critical Edition of Thomas Middleton's Your Five Gallants' (unpublished doctoral thesis, University of Michigan, 1961)

[33] Purkiss, Diane, The Witch in History: Early Modern and Twentieth-Century Representations (London and New York: Routledge, 1996)

[34] Rosen, Barbara, Witchcraft (London: Edward Arnold, 1969)

[35] Schafer, Elizabeth, The Witch: Thomas Middleton (London and New York: A and c Black, 1994)

[36] Schoenbaum, Samuel, 'Middleton's Tragicomedies', Modern Philology, 54 (1956), 7-19

[37] Scot, Reginald, Scot's Discovery of Witchcraft (1651), 1227, book III, ch. 3 .

[38] The Discovery of Witchcraft (New York: Dover publications, 1972)

[39] Shakespeare, William, Macbeth, ed. by A. R. Braunmuller (Cambridge: Cambridge University Press, 1997)

[40] The Annotated Shakespeare: Complete Works Illustrated, ed. by A. L. Rowse (London: Orbis Books, 1978), iii

[41] The Works of Shakespeare, ed. by Howard Staunton, 3 vols (London: Warne \& Routledge, 1864)
[42] The Tempest, ed. by Robert Langbaum (New York: The New American Library; London: The New English Library Limited, 1964)

[43] The Works of Shakespeare, ed. by C. H. Herford, 10 vols (London: Macmillan, 1899), iv

[44] The Complete Works of Shakespeare: including a bibliography and general Introduction, Glossary and Index of Characters, ed. by Charles Jasper Sisson (London: Odhams, 1953)

[45] The Dramatic Works of William Shakespeare, ed. by S. W. Singer, 10 vols (London: George Bell and Sons, 1884)

[46] The Tempest, ed. by Horace Howard Furness, 9 vols (London: J. B. Lippincott, 1892)

[47] The Arden Shakespeare: The Tempest, ed. by Virginia Mason Vaughan and Alden T. Vaughan, third series (London: Thomas Nelson, 1999)

[48] Cymbeline, ed. by Richard Hosley (New York and Toronto: The New American Library; London: The New English Library Limited, 1968)

[49] William Shakespeare: The Tempest, ed. by Anne Righter (Harmondsworth: Penguin, 1968)

[50] The Works of William Shakespeare, ed. by William George Clark and William Aldis Wright, 9 vols (London: Macmillan, 1866)

[51] The Complete Works of Shakespeare, ed. by Cornwall, 2 vols (London: The London Printing and Publishing Company, [1875])

[52] The Tempest, ed. by Virginia Mason Vaughan and Alden T. Vaughan, $2^{\text {nd }}$ series (London: Arden Shakespeare, 2011)

[53] The Complete Works of Shakespeare: including a bibliography and general Introduction, Glossary and Index of Characters, ed. by Charles Jasper Sisson (London: Odhams, 1953)

[54] The Works of William Shakespeare: The Tempest, ed. by Morton Luce, $4^{\text {th }}$ ed. (London: Methuen, 1938)

[55] The Works of Shakespeare, ed. by C. H. Herford, 10 vols (London: Macmillan, 1899), iv

[56] The Tempest, ed. by Frank Kermode (London: Methuen and Co., 1954)

[57] The Works of Shakespeare: Cymbeline, ed. by Nosworthy (London: Methuen, 1955)

[58] The Complete Work of Shakespeare (Oxford: The Shakespeare Head Press, 1934)

[59] Shakespeare in Twenty Volumes: The Winter's Tale and The Tempest, ed. by Sidney Lee (Boston and New York: Jefferson Press, 1906), viii

[60] The Complete Oxford Shakespeare: Comedies, ed. by Wells and Taylor, 2 vols (London: Oxford University Press, 1987)

[61] The dramatic writings of Will. Shakspere, with the notes of all the various commentators; Eighteenth Century Collections Online, $<$ http://find.galegroup.com.ezproxy3.lib.le.ac.uk/ecco/infom ark.do?\&source=gale\&prodId=ECCO\&userGroupName=lei 
cester $\&$ tabID $=$ T001\&docId $=\mathrm{CW} 3314887056 \&$ type $=$ multip age \& contentSet $=$ ECCOArticles \&version $=1.0 \&$ docLevel $=F$ ASCIMILE $>$ [accessed 16 May 2012]

[62] William Shakespeare: The Complete Works, ed. Stanley Wells and Gary Taylor, $2^{\text {nd }}$ ed. (Oxford: University Oxford Press, 2005)

[63] The Works of William Shakespeare, ed. by Henry Irving and Frank A. Marshall (London: Blackie \& Son, 1890)

[64] Simpson, Jacqueline, 'Witches and Witchbusters', Folklore, 107 (1996), 5-18

[65] Smith, Irwin, Shakespeare's Blackfriars Playhouse: Its History and Its Design (London: Peter Owen, 1964)

[66] Spencer, Christopher, Five Restoration Adaptations of Shakespeare (Urbana: University of Illinois Press, 1965)

[67] Stern, Tiffany, Making Shakespeare: From Stage to Page (London and New York: Routledge, 2004)

[68] Taylor, Gary, 'Thomas Middleton: Lives and Afterlives', in Thomas Middleton: the Collected Works, ed. by Gary Taylor and John Lavagnino (Oxford: Clarendon Press, 2007), pp. $25-58$

[69] 'The Order of Persons', in A Companion to the Collected Works: Thomas Middleton and Early Modern Textual Culture, ed. by Gary Taylor and John Lavagnino (Oxford: Oxford University Press, 2007), pp. 31-79
[70] Tolman, Albert H., 'Notes on Macbeth', PMLA, 11 (1896), 200-219

[71] Wickham, Glynne, 'To Fly Not To Fly? The Problem of Hecate in Shakespeare's "Macbeth" in Essays on Drama and Theatre, ed. by Benjamin Hunningher (Amsterdam: Baarn, 1973), pp. 17-82

[72] 'The Second Blackfriars', in English professional Theatre, 1530-1660, ed. by Glynne Wickham, Herbert Berry, and William Ingram (Cambridge: Cambridge University Press, 2000), pp. 501-504

[73] Wilson, F. P., The Witch (Britain: The Malone Society Prints, $1948(1950))$

[74] 'Slut', Oxford English Dictionary, $<$ http://www.oed.com.ezproxy4.lib.le.ac.uk/view/Entry/182 346 ?rskey $=$ WonOsL\&result $=1 \&$ isAdvanced $=$ false\# $\#$ eid $>$ [Accessed June 2011]

[75] 'Tumbler', Oxford English Dictionary, $<$ http://www.oed.com.ezproxy4.lib.le.ac.uk/view/Entry/207 355? redirectedFrom=tumbler\#eid $>$ [Accessed August 2011]

[76] 'Tumble', Oxford English Dictionary, $<$ http://www.oed.com.ezproxy4.lib.le.ac.uk/view/Entry/207 350 ? $r$ skey $=$ uldVNy\&result $=2 \&$ isAdvanced $=$ false\#eid $>$ [Accessed August 2011] 